\title{
Estimation of a Tax Gap in the Personal Income Tax by Means of National Accounts $^{\#}$
}

\author{
Savina Finardi* ${ }^{*}$ Alena Vančurová ${ }^{* *}$
}

\section{Introduction}

This article is about estimation of a tax gap in the personal income tax in the Czech Republic. The part Overview introduces the theme of tax gap in the Czech context. The chapter Methodology and Data introduces the meaning of this theme and data used for our analysis. Results and discussion includes the main results and why is important to make a further and more detailed research about tax gap in the Czech Republic. The last part is Conclusion.

\section{Overview}

The Czech Republic has had a very low level of the personal income tax in the long term. An important role of personal income tax' yield plays taxation of wages. For illustration purposes, table 1 shows development of the absolute amount of income tax collection and its annual change. On the one hand, advances on the income tax from a dependent activity are monitored and on the other hand, the tax collected, based on tax declarations and reflecting taxation of other types of incomes including incomes from an independent activity, is monitored. The collection based on tax declarations is however decreased in an unquantifiable manner due to the repayment of overcharges of employees' tax.

\# The article is elaborated as one of the results of a research project of the Department of Finance and Accounting of VŠE. The project is realized within the Institutional support of VŠE IP100040.

Ing. Savina Finardi, Ph.D. - Associate Professor; Department of Public Finance, Faculty of Finance and Accounting, University of Economics, Prague, W. Churchill Sq. 4, 13067 Prague 3; <savina.finardi@vse.cz>.

** prof. Ing. Alena Vančurová, Ph.D. - Professor; Department of Public Finance, Faculty of Finance and Accounting, University of Economics, Prague, W. Churchill Sq. 4, 13067 Prague 3; <vancura@vse.cz>. 
Tab. 1: Collection of the personal income tax and annual changes (during 2003-2013)

\begin{tabular}{|c|r|r|r|r|r|r|r|c|}
\hline Year & $\begin{array}{c}\text { PE } \\
\text { dependent } \\
\text { activity } \\
\text { (bn CZK) }\end{array}$ & $\begin{array}{c}\text { PE } \\
\text { from } \\
\text { TD } \\
\text { (bZK) }\end{array}$ & $\begin{array}{c}\text { Pependent } \\
\text { activity } \\
\text { (absolute } \\
\text { change, } \\
\text { bn CZK) }\end{array}$ & $\begin{array}{c}\text { PE from } \\
\text { TD } \\
\text { (absolute } \\
\text { change, } \\
\text { bn CZK) }\end{array}$ & $\begin{array}{c}\text { dependent } \\
\text { activity } \\
\text { (annual } \\
\text { relative } \\
\text { change) }\end{array}$ & $\begin{array}{c}\text { PE from } \\
\text { TD } \\
\text { (annual } \\
\text { relative } \\
\text { change) }\end{array}$ & $\begin{array}{c}\text { PE } \\
\text { dependent } \\
\text { activity } \\
\text { (relative } \\
\text { change of } \\
\mathbf{2 0 0 3} \text { ) }\end{array}$ & $\begin{array}{c}\text { PE from } \\
\text { TD } \\
\text { (relative } \\
\text { change } \\
\text { of 2003) }\end{array}$ \\
\hline $\mathbf{2 0 0 3}$ & 86.6 & 21.9 & $X$ & $x$ & $x$ & $x$ & x & x \\
\hline $\mathbf{2 0 0 4}$ & 94.7 & 22.1 & 8.1 & 0.2 & $9.35 \%$ & $0.91 \%$ & $9.35 \%$ & $0.91 \%$ \\
\hline $\mathbf{2 0 0 5}$ & 102.63 & 24.04 & 7.93 & 1.94 & $8.37 \%$ & $8.78 \%$ & $18.51 \%$ & $9.77 \%$ \\
\hline $\mathbf{2 0 0 6}$ & 110.66 & 26.58 & 8.03 & 2.54 & $7.82 \%$ & $10.57 \%$ & $27.78 \%$ & $21.37 \%$ \\
\hline $\mathbf{2 0 0 7}$ & 111.63 & 17.85 & 0.97 & -8.73 & $0.88 \%$ & $-32.84 \%$ & $28.90 \%$ & $-18.49 \%$ \\
\hline $\mathbf{2 0 0 8}$ & 115.18 & 17.75 & 3.55 & -0.1 & $3.18 \%$ & $-0.56 \%$ & $33.00 \%$ & $-18.95 \%$ \\
\hline $\mathbf{2 0 0 9}$ & 111.04 & 5.56 & -4.14 & -12.19 & $-3.59 \%$ & $-68.68 \%$ & $28.22 \%$ & $-74.61 \%$ \\
\hline $\mathbf{2 0 1 0}$ & 111.84 & 7.99 & 0.8 & 2.43 & $0.72 \%$ & $43.71 \%$ & $29.15 \%$ & $-63.52 \%$ \\
\hline $\mathbf{2 0 1 1}$ & 119.37 & 2.94 & 7.53 & -5.05 & $6.73 \%$ & $-63.20 \%$ & $37.84 \%$ & $-86.58 \%$ \\
\hline $\mathbf{2 0 1 2}$ & 119.79 & 3.26 & 0.42 & 0.32 & $0.35 \%$ & $10.88 \%$ & $38.33 \%$ & $-85.11 \%$ \\
\hline $\mathbf{2 0 1 3}$ & 126.13 & 2.68 & 6.34 & -0.58 & $5.29 \%$ & $-17.79 \%$ & $45.65 \%$ & $-87.76 \%$ \\
\hline
\end{tabular}

Source: ARAD ČNB.

Note: TD - tax declaration, PE - physical entities.

There is an increase of the total collection annually, except for 2009, as regards advances on the income tax from a dependent activity. There were two big falls in 2007 and 2009, as regards declaring people. In 2006 the Czech Republic switched to applying tax deductions instead of standard deductions but since 2005 a deduction on child and tax bonus have been implemented. Since 2008 tax deductions were increased, the basic deduction increased from CZK 7200 to CZK 24 840. All these changes were implemented into the tax collection in the following year (2007 and 2009). Next fall was in 2011 by CZK 5bn. In 2006 declaring people contributed to public budgets by the amount of CZK 26.6bn, the collection from these people was CZK 2.7bn for 2013. Employees' collection was CZK 126bn in 2013.

Development of the income tax collection from tax declarations could have been influenced by the decrease of number of people with incomes from an independent activity, which can, however, apply also to numbers 
Finardi, S. - Vančurová, A.: Estimation of a Tax Gap in the Personal Income Tax by Means of National Accounts.

of employees. Diagram 1 illustrates the annual development of the number of employees and self-employed people.

Fig. 1: Annual changes of the number of employees and selfemployed people during 2004 - 2012 (absolutely)

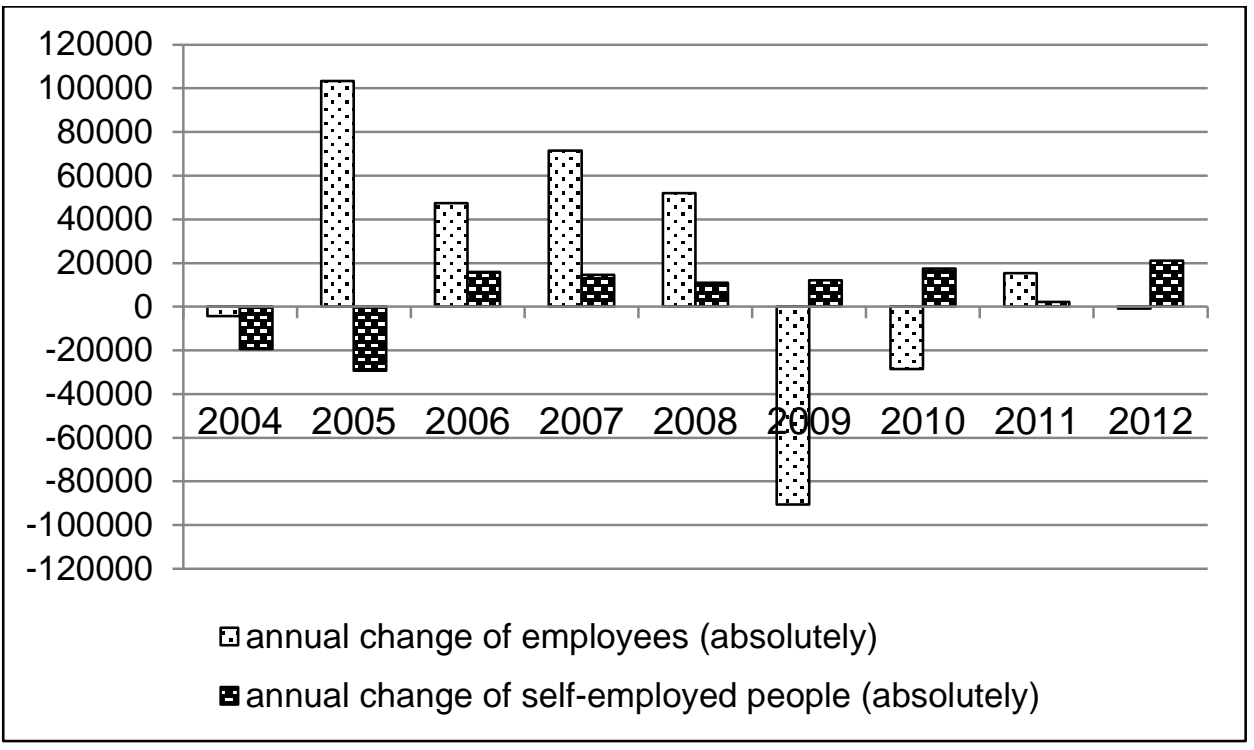

Source: Czech Statistical Office.

There was an annual increase of the number of self-employed people also in 2009 and 2010 when the Czech economy experienced a crisis. The economic crisis came out in the annual decrease of the number of employees even during these years. ${ }^{1}$ In 2011 the annual increase of selfemployed people slowed down and the increase was only 2125 people but in 2013 there was an annual increase again which exceeded 20000 people. According to the Czech Statistical Office, the absolute scale counted 4119471 employees and 908516 self-employed people. ${ }^{2}$ The

1 The question is whether the part of employees who disappeared from the labour market during the mentioned years didn't move to self-employed people (so-called Švarcsystém).

${ }^{2}$ It is so-called national concept - residents working in residential as well as nonresidential production units. The second concept is a domestic concept - residents and non-residents working in residential production units. Indeed, the number of selfemployed people is same for both concepts and only the number of employed people differs by almost 50000 on behalf of the domestic concept. 
number of people with incomes from an independent activity is of course higher but the Czech Statistical Office includes into the category of the self-employed also people who don't have incomes from a dependent activity, i.e. from employment. The ratio of the number of self-employed people on the number of employees is high and is still growing in the Czech Republic. The question is whether it is a usual relation in the international context. For comparison, surrounding smaller countries and Sweden, as an advanced European country with a similar number of inhabitants as the Czech Republic, were chosen.

Table 2 states the number of self-employed people per 1000 inhabitants. This number is highest in the Czech Republic and in 2012 it reached the value of 86.4 self-employed people per 1000 inhabitants. The Austrian and Slovak indicator is very similar - around 65 self-employed people per 1000 inhabitants. Sweden has reached the lowest value in the long term - around 25 self-employed people per 1000 inhabitants.

Tab. 2: Development of the number of self-employed people per 1000 inhabitants during 2003 - 2013

\begin{tabular}{|c|c|c|c|c|}
\hline Year & CZ & AT & SK & SE \\
\hline $\mathbf{2 0 0 3}$ & 84.7 & 62.3 & 43.8 & 26.8 \\
\hline $\mathbf{2 0 0 4}$ & 82.7 & 63.0 & 50.8 & 27.4 \\
\hline $\mathbf{2 0 0 5}$ & 79.8 & 63.4 & 53.3 & 27.2 \\
\hline $\mathbf{2 0 0 6}$ & 81.1 & 64.4 & 55.4 & 27.7 \\
\hline $\mathbf{2 0 0 7}$ & 82.0 & 64.6 & 58.6 & 28.0 \\
\hline $\mathbf{2 0 0 8}$ & 82.4 & 65.5 & 64.6 & 26.5 \\
\hline $\mathbf{2 0 0 9}$ & 83.1 & 65.4 & 67.9 & 26.6 \\
\hline $\mathbf{2 0 1 0}$ & 84.5 & 65.7 & 67.0 & 27.0 \\
\hline $\mathbf{2 0 1 1}$ & 84.6 & 65.5 & 65.6 & 25.7 \\
\hline $\mathbf{2 0 1 2}$ & 86.4 & 65.0 & 63.9 & 25.1 \\
\hline
\end{tabular}

Source: Eurostat.

In spite of a high portion of self-employed people in the Czech Republic, their contribution to the personal income tax' yield is very low and has even a decreasing tendency. We can assume that also the devastation of tax bases partakes in the low income tax collection of selfemployed people, namely not only as regards incomes from an 
independent activity. This fact can't be assigned only to the high level of lump expenses for incomes from an independent activity; the expenses increased significantly several times during the monitored period. Other probable reason is a distortion of recorded incomes. Annual differences are, however, influenced also by changes of rules for tax collection. Therefore the subject of investigation will be the estimation of a tax gap resulting from the devastation of tax bases and will provide that incomes from a dependent activity don't partake in the tax gap.

\section{Methodology and Data}

Studies of authors who concentrated on the estimation of a tax gap in the past were used for these estimations. For instance, the following studies are concerned: (Erard, 2005; Giles, 2000; Karlinsky, 2004; Mazur, 2007; McManus, 2006; Mohamed, 2012; Khwaja, 2014). The publication (Zídková, 2014) that focuses on the estimation of a tax gap in the value added tax was published recently in the Czech Republic.

The estimation of a tax gap concentrates on the rate of distortion of receipts and expenditures of people with incomes from an independent activity. The data was gathered from the Eurostat database of national accounts. The database advantage is its national comparability. The data of production (P.1) was compared with the index of intermediate consumption (P.2) and by means of these two indexes, a subsidiary index of expense-to-revenue ratio of the given sector was created which is in absolute terms a gross added value.

Gross expense - to - revenue in $\%=\frac{\text { intermediate consumtion }(P .2)}{\text { production }(P .1)}$

The final gross expense-to-revenue ratio of individual sectors was investigated from the viewpoint of a longer time line in the Czech Republic and a spatial comparison with selected EU countries was also made. Data from 1993 to 2012 is available for the Czech Republic. In case of a spatial comparison of selected EU countries, we have chosen a time line from 2000 to 2012.

Important data is also the number of self-employed people. The number of self-employed people for all sectors is stated in the attachment (table 6). This data will be used for the calculation of an estimated tax gap in given sectors.

Consequently, an average gross expense-to-revenue ratio was compared in all ranches and only the biggest absolute differences in the 
average gross expense-to-revenue ratio between the Czech Republic and the rest of monitored countries were chosen (table 3). Such differences can't be explained only by the factor of labour productivity, which is higher in Austria and Sweden. As examples can be some sectors which are very closely related to the public sector, such as $\mathrm{O}$ ) public administration, P) education and Q) health and social care. In sector O) public administration, the differences are very small as compared to the Czech Republic and Swedish average gross expense-to-revenue ratio is even by 10 percentage points higher than the Czech one. In sector Q) health and social care, differences among the Czech Republic, Austria and Sweden are very small again; Swedish average gross expense-torevenue ratio in this case is even by 11 percentage points lower. Sectors O) public administration and Q) health and social care are specific because their records of sales are treated more exactly.

The biggest absolute difference was then included into the calculation of a partial tax base from an independent activity. Exceptions were only sectors A and B where an average value of all three monitored countries was chosen because of important specifics of these sectors. Sector D Production of electricity, etc. was completely removed from calculations. This sector has its regional specifics and it has experienced also rough tax development from the viewpoint of small subjects (solar appliances, etc.). 
Finardi, S. - Vančurová, A.: Estimation of a Tax Gap in the Personal Income Tax by Means of National Accounts.

Tab. 3: Average gross expense-to-revenue ratio according to sectors in monitored countries (in \% during 2000 - 2012)

\begin{tabular}{|l|r|r|r|r|}
\hline \multicolumn{1}{|c|}{ Sector } & \multicolumn{1}{c|}{ CZ } & \multicolumn{1}{c|}{ AT } & \multicolumn{1}{c|}{ SK } & \multicolumn{1}{c|}{ SE } \\
\hline $\begin{array}{l}\text { A Agriculture, forestry and fishing } \\
\text { industry }\end{array}$ & 59.94 & 54.03 & 54.54 & 45.95 \\
\hline B Exploitation and mining & 53.16 & 47.13 & 40.39 & 50.18 \\
\hline C Manufacturing industry & 75.96 & 66.68 & 76.86 & 70.74 \\
\hline $\begin{array}{l}\text { D Production and distribution of } \\
\text { electricity, gas, heat and air- } \\
\text { conditioned air }\end{array}$ & 67.57 & 74.01 & 76.01 & 36.87 \\
\hline $\begin{array}{l}\text { E Water supply; activities related to } \\
\text { wastewater, waste and maintenance }\end{array}$ & 61.61 & 51.29 & 48.74 & 59.37 \\
\hline F Building industry & 72.27 & 56.24 & 63.03 & 56.63 \\
\hline $\begin{array}{l}\text { G Wholesale and retail; repairs and } \\
\text { maintenance of motor vehicles }\end{array}$ & 51.05 & 42.05 & 49.27 & 36.85 \\
\hline H Transport and stock-keeping & 57.46 & 51.49 & 62.56 & 61.57 \\
\hline $\begin{array}{l}\text { I Accommodation, boarding and } \\
\text { catering }\end{array}$ & 55.51 & 38.68 & 46.13 & 59.70 \\
\hline $\begin{array}{l}\text { J Information and communication } \\
\text { activities }\end{array}$ & 51.71 & 56.01 & 48.41 & 56.34 \\
\hline K Banking and insurance industry & 54.57 & 44.79 & 46.80 & 36.60 \\
\hline L Real estate activities & 51.86 & 31.92 & 27.37 & 44.38 \\
\hline $\begin{array}{l}\text { M Professional, scientific and } \\
\text { technical activities }\end{array}$ & 62.06 & 53.13 & 50.39 & 50.36 \\
\hline $\begin{array}{l}\text { N Administrative and support } \\
\text { activities }\end{array}$ & 63.40 & 36.00 & 48.54 & 49.08 \\
\hline $\begin{array}{l}\text { O Public administration and } \\
\text { defence; mandatory social security }\end{array}$ & 38.13 & 33.04 & 35.92 & 48.11 \\
\hline P Education & 26.52 & 16.02 & 23.49 & 32.17 \\
\hline Q Health and social care & 39.02 & 36.61 & 39.06 & 27.59 \\
\hline $\begin{array}{l}\text { R Cultural, entertainment and } \\
\text { recreational activities }\end{array}$ & 56.82 & 35.11 & 43.96 & 53.35 \\
\hline S Other activities & 45.89 & 45.76 & 38.27 \\
\hline
\end{tabular}

Source: Eurostat; own calculations.

It is possible to see the biggest deviations in the average gross expense-to-revenue ratio in the following sectors: F) building industry, I) accommodation, boarding and catering, K) banking and insurance 
industry, L) real estate activities, N) administrative and support activities, $\mathrm{R})$ cultural, entertainment and recreational activities.

Table 4 depicts differences in the average gross expense-to-revenue ratio as compared to the Czech Republic (only selected sectors). The differences aren't given exclusively by labour productivity but also by national specifics of the given countries. The differences are in percentage points and compare the average gross expense-to-revenue ration of the Czech Republic to other selected countries in period of $2000-2012$.

Tab. 4: Differences in the average gross expense-to-revenue ratio as compared to the Czech Republic (in p. p., total average of the period 2000 - 2012)

\begin{tabular}{|l|r|r|r|}
\hline \multicolumn{1}{|c|}{ Sector } & AT & SK & \multicolumn{1}{c|}{ SE } \\
\hline F Building industry & -16 & -9 & -16 \\
\hline I Accommodation, boarding and catering & -17 & -9 & 4 \\
\hline K Banking and insurance industry & -10 & -8 & -18 \\
\hline L Real estate activities & -20 & -24 & -7 \\
\hline N Administrative and support activities & -27 & -15 & -14 \\
\hline $\begin{array}{l}\text { R Cultural, entertainment and } \\
\text { recreational activities }\end{array}$ & -22 & -13 & -3 \\
\hline
\end{tabular}

Source: Eurostat; own calculations.

Sector coefficient $=\left(A G R_{C Z}-A G R_{\text {min }}\right)+1$

Where: $A G R$ is an average gross expense-to-revenue ratio according to sectors.

$P T B$ after correction according to sectors $=$ PTB before correction * sector coefficient

Where: PTB after correction is a partial tax base from an independent activity of the given sector after correction, PTB before correction is a partial tax base from an independent activity of the given sector before correction and coefficient is the coefficient of the biggest absolute difference in the average gross expense-to-revenue ratio of the given sector +1 .

After the quantification of a partial tax base after correction, the size of a tax gap was estimated. The nominal rate of $15 \%$ was considered for 
Finardi, S. - Vančurová, A.: Estimation of a Tax Gap in the Personal Income Tax by Means of National Accounts.

the personal income tax, it was abstracted from all tax deductions that can be applied only once.

Estimation of PIT tax gap $=$ $((P T B$ after corr. $-P T B$ before corr. $) * 0,15) *$ number of $p$.

Note: PIT - personal income tax

Furthermore, a tax gap in insurance was estimated in relevant real partial tax bases. The minimal assessed base of both subsystems in 2011 was taken into account. ${ }^{3}$ The minimal assessed base for public health insurance was CZK 148440 per year and CZK 74220 for social security insurance and allowance for the state employment policy. In case that the real assessed base didn't exceed the minimal assessed base, the tax gap in insurance wasn't included into the estimation.

Estimation of a tax gap in insurance $=(($ real $A B>\min . A B) *$ rate) * number of $p$.

Note: $\mathrm{AB}$ - assessed base

\section{Results and Discussion}

By means of the above-mentioned procedures, a tax gap for the Czech Republic was estimated, from the viewpoint of a personal income tax and insurance. Table 5 contains results of all sectors except for the following ones D) which we stopped monitoring, and O) where no self-employed people are registered. The total tax gap in the personal income tax for 2011 reached CZK 2.5bn, Nearly CZK 300 million in public health insurance and CZK 1.76bn in social security insurance and allowance for the state employment policy.

\footnotetext{
${ }^{3}$ Data about average real partial tax bases according to sectors for 2011 is available.
} 
Tab. 5: Estimation of a tax gap (in CZK)

\begin{tabular}{|c|c|c|c|}
\hline Sectors & $\begin{array}{l}\text { Tax gap } \\
\text { PIT }\end{array}$ & $\begin{array}{l}\text { Tax gap } \\
\text { PHI }\end{array}$ & $\begin{array}{l}\text { Tax gap } \\
\text { SS }\end{array}$ \\
\hline $\begin{array}{l}\text { A Agriculture, forestry and fishing } \\
\text { industry }\end{array}$ & 84904535 & 0 & 0 \\
\hline B Exploitation and mining & 144240 & 0 & 0 \\
\hline C Manufacturing industry & 196629172 & 0 & 0 \\
\hline \multicolumn{4}{|l|}{$\begin{array}{l}\text { D Production and distribution of } \\
\text { electricity, gas, heat and air- } \\
\text { conditioned air }\end{array}$} \\
\hline $\begin{array}{l}\text { E Water supply; activities related } \\
\text { to wastewater, waste and } \\
\text { maintenance }\end{array}$ & 4623679 & 0 & 0 \\
\hline F Building industry & 481948790 & 0 & 5745986 \\
\hline $\begin{array}{l}\text { G Wholesale and retail; repairs } \\
\text { and maintenance of motor vehicles }\end{array}$ & 459147133 & 0 & 393682 \\
\hline H Transport and stock-keeping & 47679294 & 0 & 59214974 \\
\hline $\begin{array}{l}\text { I Accommodation, boarding and } \\
\text { catering }\end{array}$ & 59345455 & 0 & 0 \\
\hline $\begin{array}{l}J \text { Information and communication } \\
\text { activities }\end{array}$ & 17724062 & 0 & 36519758 \\
\hline K Banking and insurance industry & 88177447 & 0 & 42062028 \\
\hline L Real estate activities & 189174315 & 0 & 0 \\
\hline $\begin{array}{l}\text { M Professional, scientific and } \\
\text { technical activities }\end{array}$ & 359771226 & 0 & 449477355 \\
\hline $\begin{array}{l}\text { N Administrative and support } \\
\text { activities }\end{array}$ & 99049997 & 0 & 9857762 \\
\hline \multicolumn{4}{|l|}{$\begin{array}{l}\text { O Public administration and } \\
\text { defence; mandatory social security }\end{array}$} \\
\hline P Education & 98262817 & 88436535 & 353725263 \\
\hline Q Health and social care & 233924508 & 210532057 & 788761769 \\
\hline $\begin{array}{l}\text { R Cultural, entertainment and } \\
\text { recreational activities }\end{array}$ & 68095710 & 0 & 15548051 \\
\hline S Other activities & 59850546 & 0 & 0 \\
\hline In total & 2548452925 & 298968592 & 1761306627 \\
\hline
\end{tabular}

Source: Own calculations.

Note: PIT - personal income tax, PHI - public health insurance, SS - social security. 
Within the revision of national accounts in 2010, the Czech Statistical Office published its own estimations of the distortion of accounting data of selected companies in the Czech Republic. Estimations concerned only small and medium-sized private non-financial companies and also nonfinancial companies under foreign control. The results show us that the rate of sales' distortion was by estimation $10.75 \%$ for all sectors in 2010 . Table 3 contains its own estimations of the rate of incomes' distortion via the average gross expense-to-revenue ratio for all sectors during $2000-$ 2012. Different values as compared to the Czech Republic are 10.88 p. p. for Austria, 3.13 p. p. for Slovakia and 10.2 p. p. for Sweden; it is the average gross expense-to-revenue ratio for 2010. Thus, these results differ only slightly from the estimations of the Czech Statistical Office.

\section{Conclusion}

The aim of this article was to estimate the size of a tax gap in the Czech Republic in 2011, based on the data of national accounts database. Aggregate data from tax declarations of people with incomes from an independent activity was also available. By means of the chosen methodology of calculations, we managed to estimate the total tax gap in the Czech Republic in 2011 and it is CZK 4.6bn - it is such a gross estimation of uncollected collection into public budgets for 2011. The limitation of these estimations is the fact that there is official reported data in the database of national accounts and it is distorted to a certain extent. Nevertheless, it is one of possibilities how to estimate the rate of a tax gap expertly.

Our estimation gives results about size of tax gap in personal income tax, social contributions and health insurance. It should be mentioned that our estimations are based on real data, thus the tax gap could be more than 4,6bn in year 2011. These days the Czech Ministry of Finance is introducing a new approach how to make a registration of sales more transparent. It is also obvious that this approach does not cover all sectors of economy but only some of them.

\section{References}

Erard, B. (2005): Toward a Framework for Tax Gap Estimation and Microsimulation Analysis of Tax Noncompliance. Washington, D. C., National Tax Association.

Eurostat, Národní účty. Online databáze. 
Giles, D. E. A. (2000): Modelling the Hidden Economy and the Tax Gap in New Zealand. Studies in Empirical Economics. Empirical Economics, vol. 24, no. 4, 1999. Heidelberg and New York, Physica.

Hronová, S. et al. (2009): Národní účetnictví. Nástroj popisu globální ekonomiky. Praha, C. H. Beck.

Karlinsky, S. (2004): Perceptions of Tax Evasion as a Crime. eJournal of Tax Research, 2004, vol. 2, no. 2, pp. 226-40.

Khwaja, M. S. (2014): Revenue Potential, Tax Space, and Tax Gap: A Comparative Analysis. The World Bank, Policy Research Working Paper Series no. 6868.

MacKie-Mason, J. K. (1992): The Corporate Tax Gap: Evidence on Tax Compliance by Small Corporations: Commentary. Ann Arbor, University of Michigan Press.

Mazur, M. J. et al. (2007): Understanding the Tax Gap. National Tax Journal.

McClellan, C. (2013): The Consequences of Poor Tax Administration: Collections, Growth, and Corruption. Georgia State University.

McManus, J. et al. (2006): The Case for Measuring Tax Gap. eJournal of Tax Research, vol. 4, no. 1, pp. 61-79.

Mohamed, M. (2012): Estimating the Underground Economy from the Tax Gap: The Case of Malaysia. Malaysian Journal of Economic Studies, vol. 49, no. 2, pp. 91-109.

Moravcová, J. (2012): Daňové úniky v oblasti zdanění spotřeby. Bakalářská práce. Praha, Vysoká škola ekonomická v Praze.

Průša, L. et al. (2008): Sociálně ekonomické postavení osob samostatně výdělečně činných ve společnosti II. Praha, VÚPSV, Praha.

Rice, E. M. (1992): The Corporate Tax Gap: Evidence on Tax Compliance by Small Corporations. Ann Arbor, University of Michigan Press.

Taiebnia, A. et al. (2008): Underground Economy and Tax Gap.

Zídková, H. (2014): Analýza mezery DPH. Disertační práce. Praha, Vysoká škola ekonomická v Praze. 


\title{
Estimation of a Tax Gap in the Personal Income Tax by Means of National Accounts
}

\begin{abstract}
The article deals with the estimation of a tax gap incurred by devastation of a tax base and concentrates on undervaluation of incomes from an independent activity. The distortion rate was estimated by means of database data from national accounts; the database is internationally comparable. The authors built on indexes that monitor production and intermediate consumption in monitored economies and which are similar to the Czech Republic in some aspects - this concerns Slovakia, Sweden and Austria. Based on these calculations, real tax bases of people with incomes from an independent activity were set. The result of our paper is a total tax gap in the Czech Republic in 2011 and it is CZK 4,6bn - it is such a gross estimation of uncollected collection into public budgets for 2011
\end{abstract}

Key words: Tax Gap; Personal Income Tax; National Accounts; Czech Republic.

JEL classification: $\mathrm{H} 26$ 